\title{
24. NOTES ON AN ENIGMATIC SILICEOUS CYST, MIDDLE AMERICA TRENCH, DEEP SEA DRILLING PROJECT HOLE 4901
}

\author{
Herbert Stradner and Franz Allram, Geologische Bundesanstalt, A-1031 Vienna, Austria
}

We found a siliceous cyst, presumably derived from a nannoplanktonic unicellular flagellate or alga of hitherto indeterminable systematic affiliation, in the Quaternary deep-sea mud of Hole 490 in the Middle America Trench slope. It is considered to be a cold-water indicator.

\section{DESCRIPTION}

The siliceous cyst (Plate 1, Figs. 1-4) is a hollow "spheroid" showing tetrahedral symmetry and consisting of four hexagonal, curved body plates that support four subcircular flanges enclosing a large opening. Fitting into these flanges are four domed, hat-shaped plates (or shields) that seal the four subcircular openings of the cyst and can be thrown off upon evacuation of the living contents of the cyst. The four body plates are connected by the shorter flanks of their hexagonal outline. The alternating longer flanks seem to contribute to the construction of the flanges. Each flat flange (Figs. 2 and 3) has an elevated rim, as if to keep the shield from sliding off. The shields, which fit snugly into the flanges, have reinforced rims, conical walls, and flattened tops decorated by small central knobs. Also, the hexangular body plates have flat humps with a tiny knob in the center. Dimensions are 4 to $5 \mu \mathrm{m}$ in diameter.

\section{OCCURRENCE AND DISTRIBUTION}

The siliceous cyst in Plate 1 was found in Sample 490$1-4,25-26 \mathrm{~cm}$ in a sediment rich in calcareous nannoplankton as well as in siliceous microfossils (diatoms, silicoflagellates, radiolarians). It belongs to Zone NN20, which is middle to late Quaternary. This cyst was difficult to recognize owing to its small dimensions and is rather rare. Autochthony is possible but not certain. For a detailed description of the core see the site chapter for Site 490 (this volume).

\section{DISCUSSION}

Siliceous cysts of similar geometric features were first found, in abundance, by Nishida (1979) in the Subarctic Current of the Northern Pacific at $48^{\circ} \mathrm{N}$ and $164^{\circ} \mathrm{E}$ at a

\footnotetext{
${ }^{1}$ Initial Reports of the Deep Sea Drilling Project, Volume 66.
}

water temperature of $9^{\circ} \mathrm{C}$. He illustrated two different types, regarded as "genus \& species indeterminable." Silver et al. (1980) found such cysts with heavy ornamentation together with choanoflagellates below the ice in the Weddell Sea at $74^{\circ} \mathrm{S}$ and $38^{\circ} \mathrm{W}$ at water temperatures averaging $-1.8^{\circ} \mathrm{C}$, with a salinity of $34.3 \%$. Abundance is approximately $10^{5}$ cells per liter. A possible relation to the choanoflagellates was assumed, but could not be proven yet.

Booth et al. (1980) found similar siliceous cysts in the Gulf of Alaska at 56 to $57^{\circ} \mathrm{N}$ and 136 to $149^{\circ} \mathrm{W}$. They were able to distinguish nine different types, to which they gave a numerical nomenclature (Types I-IX, Booth et al., in press). Like Booth et al. and Silver et al. we assume that these forms are cysts, of which the producing organisms cannot yet be ascertained. Therefore we refrain from naming the cysts as though they were new organisms.

Until data on the cyst-forming processes in monospecific cultures are available, the systematic assignment of the these cysts will remain an open question (Booth et al., 1980). The specimens in the Middle America Trench are the first in fossil form recovered from a deep sea core. Presumably they preferred cool water and may have been transported to their Quaternary strata by cold-water currents at greater depth. If they are autochthonous, they could serve as climatic indicators.

\section{ACKNOWLEDGMENTS}

For friendly discussion and helpful advice the authors thank David Bukry, U.S. Geological Survey, La Jolla; Beatrice Booth, University of Washington; Mary Silver, University of California, Santa Cruz; and staff scientist Thomas Shipley, Scripps Institution of Oceanography, University of California, San Diego.

\section{REFERENCES}

Booth, B. C., Lewin, J., and Norris, R. E., 1980. Siliceous nannoplankton. Newly discovered cysts from the Gulf of Alaska. Mar. Biol., 58(3):205-209.

1981. Silicified cysts in North Pacific nannoplankton. Biol. Oceanog., 1(1):57-80.

Nishida, S., 1979. Atlas of Pacific Nannoplanktons. NOM (News of Osaka Micropaleontologists) Special Paper No. 3.

Silver, M. W., Mitchell, J. G., and Ringo, D. L., 1980. Siliceous nannoplankton: II. Newly discovered cysts and abundant choanoflagellates from the Weddell Sea, Antarctica. Mar. Biol., 58(3): 211-217. 


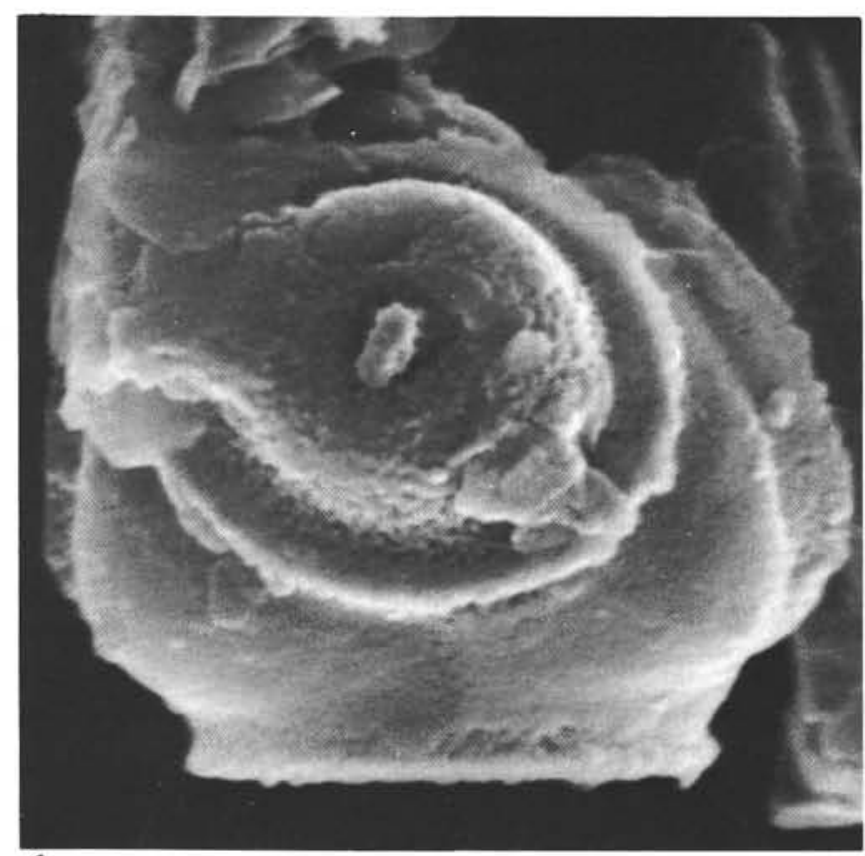

1

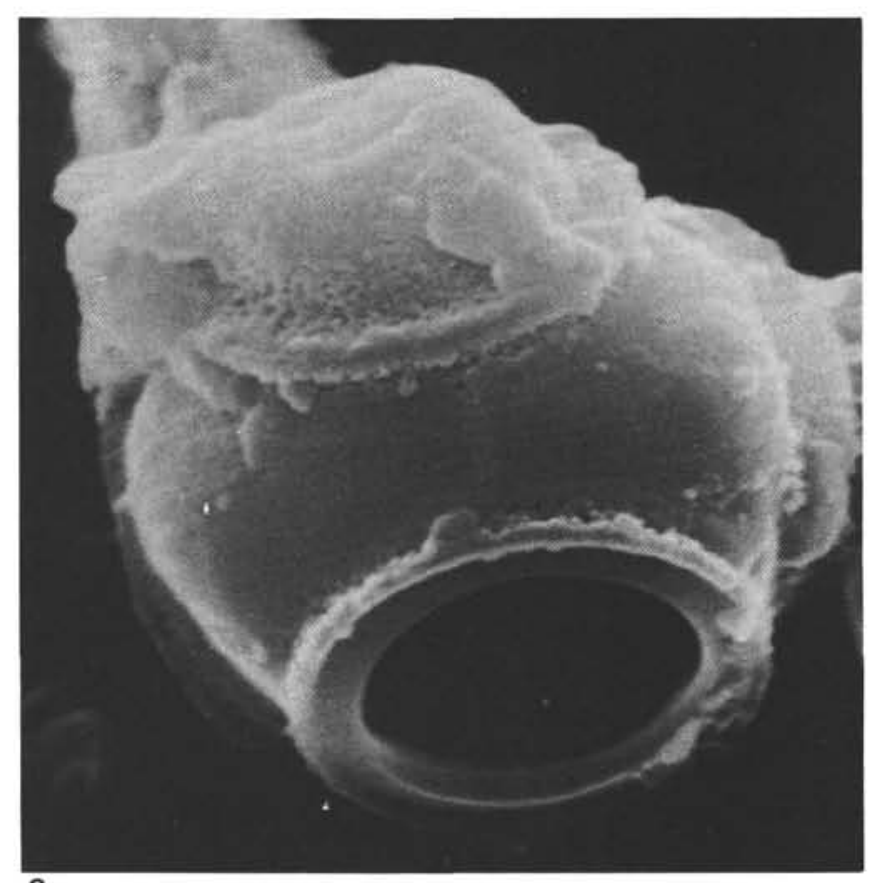

3

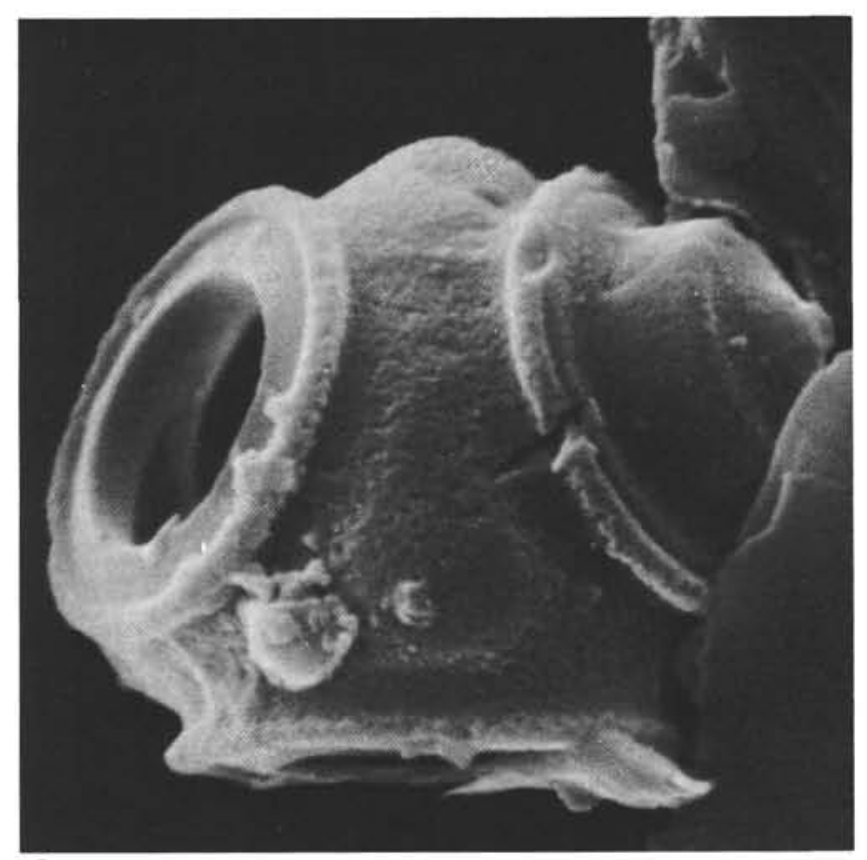

2

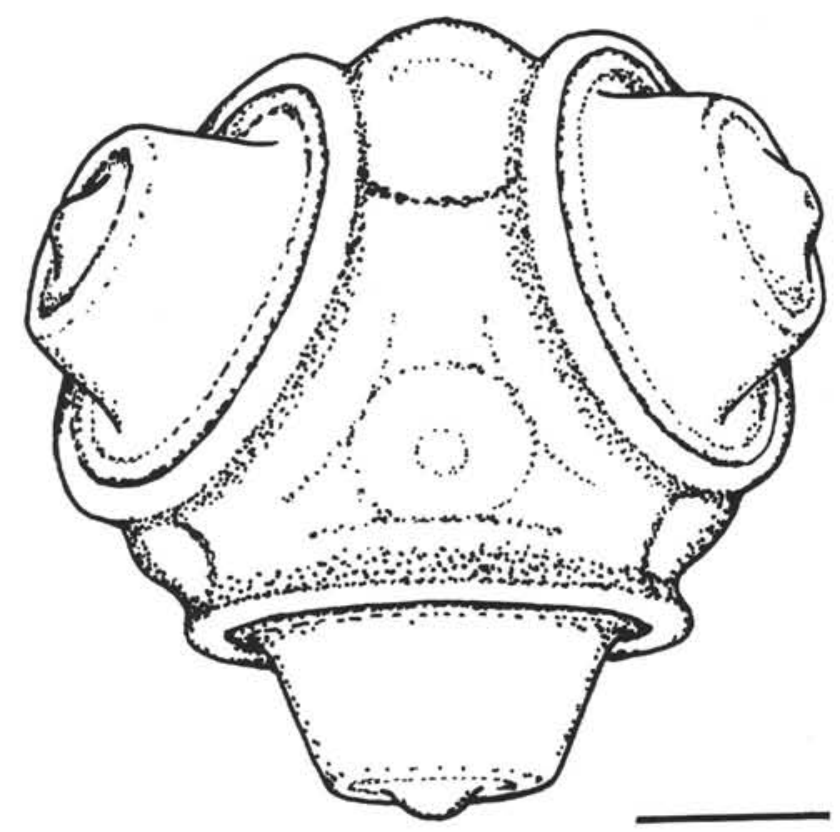

4

Plate 1. Enigmatic siliceous cyst, genus and species indeterminable (choanoflagellate cyst? Silver et al., 1980; Booth et al., 1980). (SEM, negatives at the Geological Survey of Austria Electronmicroscopical Laboratory, Vienna; scale bar $=1 \mu \mathrm{m}$; Sample 490-1-4, 25-26 cm). 1 . Cyst with shield seen from above. 2. Same specimen tilted to show flange surrounding the subcircular opening (escape window). 3. Another cyst showing framework of body plates, shield, and flanges. 4. Reconstruction of complete cyst based on specimen shown in Figure 3. 